\title{
Ilmu Bimbingan dan Konseling, Nilai dan Kesejahteraan Individu: Studi Literatur
}

\author{
Rezki Hariko \\ Universitas Negeri Padang \\ e-mail: hariko@konselor.org
}

\begin{abstract}
Abstrak
Ilmu bimbingan dan konseling didefiniskan sebagai suatu kajian komprehensif tentang prosedur atau langkah-langkah pemberian bantuan terhadap individu (klien) dalam upayanya untuk mengembangkan diri, mengentaskan permasalahan dan tujuan-tujuan khusus lainnya. Hubungan ilmu bimbingan dan konseling dengan nilai-nilai kemanusiaan menimbulkan banyak konsekuensi terhadap kehidupan manusia, baik secara langsung maupun tidak langsung. Bimbingan dan konseling terkait erat dengan kesejahteraan manusia sebagai tujuan utama kehidupan individu yang tidak dapat terlepas dari nilai-nilai yang berlaku dan berkembang di tengah-tengah masyarakat yang berbudaya. Penerapan dan pengembangan keilmuan bimbingan dan konseling hendaknya senantiasa mempertimbangkan aspek-aspek nilai yang dianut oleh individu, yang dirumuskan dalam kode etik suatu profesi atau keilmuawan.
\end{abstract}

Kata Kunci: ilmu bimbingan dan konseling, nilai, kesejahteraan

Copyright (C) 2016 IICET (Indonesia) - All Rights Reserved Indonesian Institute for Counseling, Education and Theraphy (IICET)

\section{PENDAHULUAN}

Manusia dapat menikmati berbagai fakta dan peristiwa sepanjang waktu dan sejarah kehidupannya. Manusia mengetahui berbagai realitas tersebut melalui bermacam-macam pengalaman yang dilaluinya dalam hidup. Dalam sejarah pemikiran filsafat, teori pengetahuan ini termasuk salah satu cabang filsafat yang di dalamnya dibicarakan masalah yang berkenaan dengan hakikat, sumber, cara dan prosedur memperolehnya ataupun yang menyangkut nilai pengetahuan itu sendiri.

Dalam sejarah perkembanga filsafat, Socrates, Plato dan Aristoteles sebagai tokoh tertua dalam perjalanan filsafat sebenarnya telah banyak mempersoalkan dan membahas tentang masalah pengetahuan. Namun, problem ini baru dalam proses tradisi filsafat barat melaui teori kritisme yang dikemukakan oleh Immanuel Kant. John Locke (1632-1704 M) seorang filusuf Inggris menyebutkan bahwa pengetahuan adalah bukti nyata realitas manusia dalam mengisi kehidupannya dan karenanya mendapat tempat teratas dalam keseluruhan problematika dunia filsafat. Pada abad 17-19 M, banyak filusuf yang mencurahkan perhatiannya pada bidang teori pengetahuan terutama Berkeley, David Hume, dan Augus Comte yang mengikuti langkah John Locke (Muhmidayeli, 2013).

Pengetahuan pada hakikatnya akan selalu bersifat relasional, yaitu adanya hubungan interdependensi antar subjek dan objek. Dengan mengetahui subjek akan menjadi manunggal dengan objek. Kemanunggalannya bukanlah dalam bentuk yang ekstrinsik dimana ada jarak yang membatasi hubungan keduanya. Hubungannya sangat mendalam dan bersifat intrinsik, di mana hubungannya tidak sekadar pertemuan antara subjek dan objek, tetapi benar-benar menyatu dalam suatu kesatuan yang tidak terlepaskan (Pranarka, 1987). Penyatuan subjek dan objek dalam pengertian ini tidaklah mudah dalam implementasinya. Hal ini terutama bila dilihat dari kesukaran yang ditimbulkan dari pola hubungan ini yang tidak mugkin akan sempurna diakibatkan oleh dominasi masing-masing komponen, di samping masalah lain yang tidak mungkin dielakkan.

Demikian pula halnya dengan bimbingan dan konseling, suatu ilmu yang dalam aplikasinya berkaitan dengan proses interaksi antara konselor dengan klien sebagai subjek dan objek keilmuannya. Konselor sebagai pelaksanan bimbingan dan konseling membantu orang yang tengah bergulat dengan berbagai permasalahan pribadi; sosial, belajar, karir, dana speklainnya. Menurut Dixon \& Glover, 1984; Fretz, 1982; 
Heppner, 1978a; Heppner, Cooper, Mulholland, \& Wei, 2001; Horan, 1979 (Hepner, P. P., Wampold, B.E., \& Kivlinghan, 2008) sebagai tenaga profesional konselor bertanggung jawab untuk tidak hanya meningkatkan kesejahteraan orang-orang yang mencari layanan bimbingan dan konseling, tetapi juga melindungi klien dari bahaya. Dengan demikian, sebagai tenaga profesional konselor harus secara terus-menerus memperbarui dan memperluas pengetahuan tentang manusia dan bidang bimbingan dan konseling serta mengevaluasi pelayanan, terutama karena sifat yang diterapkan dari pekerjaan ini mempengaruhi kehidupan sehari-hari dari ribuan orang. Terkait dengan hal ini tentu saja seorang konselor dalam memperbarui, memperluas dan mengaplikasikan keilmuannya harus senantiasa berpegang teguh pada penerapan nilai-nilai yang sesuai dengan nilai kemanusiaan yang dianut secara luas oleh masyarakat.

Artikel ini ditulis untuk dengan tujuan untuk membahas hal-hal yang terkait dengan beberapa bimbingan dan konseling. Secara khusus pembahasan meliputi definisi ilmu secara umum dan ilmu bimbingan dan konseling, pemahaman tentang nilai, serta hubungan ilmu bimbingan dan konseling, nilai dan kesejahteraan manusia.

\section{Bimbingan dan Konseling sebagai Ilmu Definisi Ilmu}

Upaya untuk memahami ilmu dapat dilakukan dengan cara memahami terlebih dahulu tentang istilah atau definisi ilmu itu sendiri, baik secara etimologis maupun secara konseptual. Pemahaman ilmu secara etimologis dapat diartikan sebagai upaya penelusuran istilah berdasarkan asal usul istilah ilmu itu sendiri, sedangkan pemahaman ilmu secara konseptual merupakan pengertian ilmu dari sudut konsep yang melakukan kajian konseptual terhadap sisi atau substansi dari istilah ilmu tersebut (Hanurawan (2012).

Secara etimologis istilah ilmu dalam berbagai referensi berbahasa Inggris menggunakan istilah science. Menurut Sadulloh (2008) istilah science berasal dari bahasa Latin yaitu scire yang dalam bahasa Inggris diatikan sebagai to know, dimana dalam artian sempit diartikan sebagai ilmu pengetahuan alam yang sifatnya kuantitaif dan objektif. Sejalan dengan pendapat tersebut, menurut Hanurawan (2012) istilah science merupakan turunan (derivasi) atau hasil dari proses adaptasi dari istilah scientia yang berasal dari bahasa Latin yang secara harfiah istilah Latin scientia memiliki makna sebagai aktivitas-aktivitas untuk mengetahui.

Menurut Hepner, Wampold, \& Kivlinghan (2008) ilmu merupakan cara untuk mengetahui, cara membangun basis pengetahuan yang relevan untuk profesi Menurut Marczyk (Hanurawan, 2012) ilmu secara konseptual didefinisikan secara sederhana sebagai suatu pendekatan metodologis dan sistematik untuk memperoleh pengetahuan baru. Definisi ini memberikan gambaran umum tentang ciri-ciri yang membedakan pengetahuan keilmuan yang dimiliki oleh para ilmuwan dengan pengetahuan biasa (ordinary knowledge) yang dimiliki oleh orang-orang awam. Para ilmuwan memperoleh ilmu pengetahuan melalui observasi secara cermat dan menggunakan pendekatan yang bersifat sistematis, terkontrol dan metodologis. Lebih terkait dengan hal ini menurut Hepner, Wampold, \& Kivlinghan (2008) Metode ilmiah adalah seperangkat asumsi dan aturan tentang mengumpulkan dan mengevaluasi data. Pusat untuk metode ilmiah adalah pengumpulan data yang memungkinkan seorang ilmuwan untuk menempatkan ide-ide mereka melalui sebuah tes empiris, di luar atau terpisah dari bias pribadi.

\section{Ilmu Bimbingan dan Konseling}

Untuk memahami definisi bimbingan dan konseling dapat ditinjau dari masing-masing kata yang menyusunnya, maupun gabungan kata yang membentuk frasa. Bimbingan didefinisikan sebagai proses membantu individu dalam menentukan pilihan penting yang mempengaruhi kehidupannya. Sementara itu, konseling didefinisikan sebagai aplikasi kesehatan mental prinsip-prinsip psikologis/perkembangan manusia melalui intervensi kognitif, afektif, perilaku, atau sistemik (Gladding, 2012). Tanpa memisahkan arti dari kata-kata yang menyusun frasa, Gibson \& Mitchel (2011) mendefiniskan bimbingan dan konseling sebagai pelayanan bantuan untuk peserta didik baik individu atau kelompok agar mandiri dan berkembang secara optimal dalam hubungan pribadi, sosial, belajar, karir; melalui berbagai jenis layanan dan kegiatan pendukung atas dasar norma-norma yang berlaku. Secara umum bimbingan dan konseling dapat didefiniskan sebagai proses pemberian bantuan yang dilakukan melalui wawancara konseling oleh seorang ahli yang disebut sebagai konselor kepada individu yang sedang mengalami sesuatu masalah yang bermuara pada teratasinya masalah yang dihadapi konseli serta dapat memanfaatkan berbagai potensi yang dimiliki dan sarana yang ada, sehingga individu atau kelompok individu itu dapat memahami dirinya sendiri untuk mencapai perkembangan yang optimal, mandiri serta dapat merencanakan masa depan yang lebih baik untuk mencapai kesejahteraan hidup.

Bimbingan dan konseling merupakan suatu ilmu yang berusaha memfasiltasi pertumbuhan dan perkembangan individu. Ilmu bimbingan dan konseling lebih jauh menjadi kerangka pelaksanaan profesi 
bimbingan dan konseling. Menurut Hepner, Wampold, \& Kivlinghan (2008) suatu profesi yang bertujuan untuk memfasilitasi pertumbuhan dan perubahan positif dalam klien harus didasarkan sebanyak mungkin pada pengetahuan yang ada pada sebuah realitas di luar keyakinan pribadi dan prasangkapenyandang profesi. Oleh karena itu, sejumlah metode ilmiah dikembangkan untuk membuat pengetahuan tersebut. Ilmu memainkan peran penting dalam pengembangan pengetahuan sebagai dasar bagi profesi bimbingan dan konseling.

Seperti halnya ilmu-ilmu lain, bimbingan dan konseling sebagai suatu disiplin ilmu berkaitan dengan berbagai disiplin ilmu lain yang dijadikan sebagai fondasi. Tidak dapat disangkal, kebanyakan fondasi tersebut bersumber dari disiplin keilmuan psikologi, seperti: psikologi pendidikan, psikologi sosial, psikologi ekologis, psikologi perkembangan, psikologi kepribadian dan psikologi konseling. Kontribusi ilmu psikologi meliputi teori dan proses konseling, asesmen standar, teknik konseling individu dan kelompok, dan pengembangan karir serta teori-teori pengambilan keputusan. Ilmu psikologi memiliki kontribusi yang besar terhadap bangunan pengetahan keilmuan bimbingan dan konseling terutama dari bidang psikologi pendidikan beserta kajian-kajiannya tentang teori belajar, pertumbuhan dan perkembangan manusia dan implikasinya bagi lingkup pendidikan (Gibson, R.L. \& Mitchel, 2011).

Namun demikian, hal yang tidak boleh dikesampingkan bahwa beberapa keilmuan lain juga memperkaya ilmu bimbingan dan konseling. Hal inilah yang memunculkan berbagai paradigm dalam pelaksanaan bimbingan dan konseling, seperti: paradigm medis organis, system ikrelasional, kontekstual, dan psikologis (Cottone, 1992). Ilmu sosiologi berkontribusi dalam memberi pengertian tentang kelompokkelompok manusia dan pengaruhnya terhadap pranata dan perubahan sosial. Antropologi membantu para konselor dalam memahami manusia berdasarkan pemahaman terhadap budaya-budaya yang dimiliki manusia tersebut, yang pada gilirannya menyediakan rambu-rambu bagi cara bersikap dan memandang anggotaanggotanya. Biologi membantu konselor memahami organisme manusia beserta segala keunikannya. Ilmu kesehatan membantu konselor dalam memahami pentingnya kesejahteraan hidup dan pencegahan dari penyakit, penyimpangan dan gangguan baik mental mapun fisik (Gibson, R.L. \& Mitchel, 2011).

Berbagai keilmuan lain yang juga menempatkan manusia sebagai objek dan subjek bahasannya, diyakini terkait dengan bimbingan dan konseling. Meskipun tidak dapat dinafikan, memang, pada faktanya psikologi dijadikan dan dianggap sebagai ilmu yang paling mendominasi warna keilmuan bimbingan dan konseling. Sebuah pemandangan umum yang tergambar dari jenis-jenis mata kuliah yang dibelajarkan terhadap mahasiswa bimbingan dan konseling. Suatu anggapan umum yang harus kembali ditinjau dan disangsikan.

Sebagai sebuah ilmu yang mandiri, bimbingan dan konseling berupaya untuk meletakkan ilmu-ilmu lain sebagai dasar dalam membangun keilmuannya. Sebagai hasilnya, bimbingan dan konseling memiliki berbagai teknik dan keterampilan yang digunakan untuk mencapai tujuan tersebut. Tujuan utama menggunakan teknik dan keterampilan tersebut adalah untuk membantu klien mengembangkan keterampilan pribadi dan inner streght agar mereka dapat menciptakan kebahagiaan di dalam kehidupannya sendiri dan orang lain (Nelson-Jones, 2009).

Berdasarkan paparan yang telah dikemukakan, bimbingan dan konseling mengaplikasikan ilmu-ilmu lain yang umumnya sama-sama mengkaji tentang manusia sebagai dasar teori, membentuk sebuah gugusan ilmu tersendiri. Dengan demikian dapat dikemukakan rumusan tentang definisi ilmu bimbingan dan konseling yaitu suatu kajian komprehensif tentang prosedur atau langkah-langkah dalam memberikan bantuan terhadap individu (klien) dalam upayanya untuk mengembangkan diri dan mengentaskan permasalahan klien yang mencakup segenap aspek kehidupannya. Suatu upaya perumusan tentang definisi bimbingan dan konseling yang membutuhkan kajian mendalam mengenai aspek ontologi, epistimologi dan aksiologinya.

\section{Pemahaman Tentang Nilai}

Manusia merupakan makhluk budaya dan makhluk sosial (Syam, 1996; Jalaluddin \& Idi, 2014). Sebagai makhluk sosial, manusia selalu hidup bersama dalam artian bahwa manusia hidup dalam interaksi dan interdependensi antar sesamanya. Manusia tidak akan dapat memenuhi segala kebutuhannya tanpa adanya bantuan dari orang lain. Karena pada dasarnya setiap manusia saling membutuhkan sesamanya baik dari segi jasmaniah; segi-segi ekonomis, maupun rohaniah; sosial dan cinta.

Menurut Ahmadi (Jalaluddin \& Idi, 2014) dalam rangka mengembangkan dan menjaga eksistensinya sebagai makhluk sosial, manusia senantiasa berhadapan dengan masalah-masalah sosial yang bersinggungan langsung dengan nilai-nilai. Pada prinsipnya manusia memerlukan nilai-nilai dalam proses interaksinya. Dengan demikian nilai-nilai akan selalu muncul dalam kehidupan manusia yaitu ketika manusia mengadakan hubungan sosial atau kegiatan bermasyarakat dengan manusia lainnya.

Secara umum cakupan pengertian nilai adalah sangat luas. Segala sesuatu yang ada di dunia ini adalah bernilai yang mana dalam filsafat dikenal sebagai aksiologi, yaitu menyangkut hal-hal yang berupa 
pertanyaan-pertanyaan tentang apakah sesuatu yang baik dan bagus tersebut (Syam, 1996; Jalaluddin \& Idi, 2014). Sejalan dengan hal tersebut, menurut Muhmidayeli (2013) studi tentang nilai dikenal dengan aksiologi yang meliputi empat pertanyaan utama, yaitu: (1) apak nilai itu subjektif atau objektif atau apakah nilai itu personal atau impersonal, (2) apakah nilai itu berubah atau konstan, dan (3) adakah hierarkis dalam nilai itu dan (4) dapatkah nilai itu diajarkan? Lebih lanjut dapat dikemukakan bahwa aksiologi sebagai cabang filsafat yang berkaitan dengan nilai dibedakan menjadi dua, yaitu: (1) etika; adat kebiasaan, dan (2) estetika; nilainilai yang berkaitan dengan kreasi seni (Sadulloh, 2008).

Encyclopedia Britania (Syam, 1996) memaparkan bahwa nilai adalah suatu penetapan atau suatu kualitas sesuatu objek yang menyangkut suatu jenis apresiasi atau minat. Muhmidayeli (2013) menyatakan bahwa nilai adalah gambaran tentang sesuatu yang indah dan menarik, yang mempesona, yang menakjubkan, yang membuat bahagia, senang dan merupakan sesuatu yang menjadikan seseorang atau sekelompok orang ingin memilikinya yang dapat diartikan dalam makna benar dan salah, baik dan buruk, manfaat atau berguna, indah dan jelek, dan lain sebagainya. Rohmat (2004) mendefiniskan nilai merupakan rujukan dan keyakinan dalam menentukan pilihan. Dengan demikian dapat disimpulkan bahwa nilai pada dasarnya disebut sebagai standar penuntun dalam menentukan sesuatu itu baik, indah, berharga atau tidak, yang dijadikan sebagai rujukan dan keyakinan dalam melakukan suatu tindakan.

Bimbingan dan konseling sebagai suatu ilmu berkembang dengan berlandaskan pada nilai-nilai tertentu. Nilai-nilai yang terdapat pada bimbingan dan koseling berpedoman kepada Pancasila dan Undangundang Dasar 1945. Lebih rinci, rumusan tentang nilai-nilai ini termuat dalam gubahan yang disusun oleh organisasi profesional yang memayungi bimbingan dan konseling, yaitu Asosiasi Bimbingan dan Konseling Indonesia (ABKIN). Hal inilah yang menjadi dasar pembeda keilmuan dan praktik bimbingan dan konseling Indonesia dengan Negara lain, terutama dengan Negara-negara Barat. Secara lebih khusus, bimbingan dan konseling Indonesia memegang teguh dan memadukan nilai-nilai keagamaan yang juga menjadi corak khas setiap kegiatan masyarakatnya.

\section{Hubungan Ilmu Bimbingan dan Konseling, Nilai dan Kesejahteraan Manusia}

Secara umum hubungan antara ilmu dan nilai-nilai kemanusian tidak menimbulkan banyak masalah pada eksplorasi ilmiah atau penelitian dalam bidang ilmu alam. Hal ini dikarenakan oleh karena sebagaian besar objek-objek kajian dari ilmu alam adalah benda mati atau hewan. Meskipun demikian, ilmu alam tetap akan menemui permasalahan manakala diterapkan pada kehidupan nyata. Dengan demikian, bagaimanapun ilmu alam tidak dapat melepaskan diri dari pertimbangan-pertimbangan nilai yang diyakini oleh suatu komunitas masyarakat.

Demikian pula halnya pada ilmu-ilmu sosial, salah satunya bimbingan dan konseling, yang mengadakan kontak langsung dengan manusia dalam pengembangan keilmuan maupun praktik keilmuannya. Sebagai sebuah disiplin ilmu, pengembangan ilmu bimbingan dan konseling dilakukan dengan menyelenggarakan sejumlah penelitian dengan menggunakan metode ilmiah dan melibatkan manusia sebagai partisipannya. Penggunaan metoda ilmiah yang bervariasi tidak boleh mengabaikan pentingnya mempertimbangkan aspek nilai, sehingga tidak menciderai nilai-nilai yang diyakini oleh partisipan, baik individu perorangan ataupun kelompok masyarakat. Demikian juga halnya dalam pelaksanaan praktik keilmuan bimbingan dan konseling, konselor bekerja dan berhadapan langsung dengan manusia yang menganut nilai yang mungkin sangat berbeda dengan nilai yang dianut oleh konselor dan masyarakat pada umumnya.

Menurut (Leilich, 2004) dalil dari Max Weber tentang bebas nilai (value-freedom) yang meminta agar ilmuwan sosial menjauhkan diri dari pertimbangan nilai terkait dengan materi pokok yang menjadi objek kajian penelitian, sering salah dalam pemaknaannya. Konsep bebas nilai ini hendaklah diterapkan dalam menterjemahkan hasil yang diperoleh dari proses penelitian yang dilakukan. Ilmuwan hendaknya mampu menggambarkan secara objektif dan netral hasil yang diperolehnya tanpa dikacaukan dengan pertimbanganpertimbangan yang bersifat subjektif dan tidak ilmiah.

Menurut Hepner, P. P., Wampold, B.E., \& Kivlinghan (2008) cara terbaik untuk membangun basis pengetahuan yang kredibel (cara mengetahui) adalah melalui metode penyelidikan yang sistematis dan terkontrol, yang dikenal sebagai metode ilmiah. Dalam pelaksanaan penelitian bidang bimbingan dan konseling, peneliti mesti mempertimbangkan nilai-nilai yang dianut oleh partisipannya, misalnya nilai agama, budaya dan sosial. Selain itu peneliti juga harus secara profesional memantau partisipan agar selama proses penelitian tetap memperoleh haknya dengan baik sebagai manusia yang beradab. Pertimbangan nilai sangat penting dalam penerapan ilmu bimbingan dan konseling.

Beberapa nilai utama yang harus senantiasa diterapkan oleh konselor yaitu, kerahasiaan, kesukarelaan dan keterbukaan serta pengambilan keputusan oleh klien, nilai-nilai utama tersebut disebut juga sebagai etika 
dasar dalam penyelenggaraan bimbingan dan konseling (Hansen, Stevic, \& Warner, 1982;Munro, 1985; Gibson, \& Mitchel, 2011). Secara keseluruhan tujuan pengembangan dan penerapan ilmu bimbingan dan konseling adalah tercapainya kesejahteraan manusia, yaitu manusia yang terbebas dari kungkungan masalah sehingga dapat meningkatkan kualitas kehidupan dan mampu menjalankan kehidupan kesehariannya denga efektif.

Terkait dengan pengembangan bidang bimbingan dan konseling, menurut Hepner, Wampold, \& Kivlinghan (2008) konselor sebagai pelaksana dan peneliti mesti memperhatikan beberapa etika dasar yang harus diterapkan dalam penelitian bidang bimbingan dan konseling, yaitu: (1) menekankan pada upaya yang tidak membahayakan (nonmaleficence), (2) mempertimbangkan aspek kebermanfaatan (beneficence), (3) kemadirian (autonomy), (4) keadilan (justice), dan (5) ketaatan (fidelity). Sehubungan dengan pertimbangan terhadap upaya yang tidak membahayakan, Diener dan Crandall (Hepner, Wampold, \& Kivlinghan (2008) secara ringkas menyimpulkan bahwa pedoman yang paling dasar bagi para ilmuwan sosial adalah bahwa subjek tidak akan dirugikan dengan berpartisipasi dalam penelitian. Dalam hal ini tercakup isu utama yang terkait dengan kerahasiaan data partisipan atau klien.

Beauchamp dan Childress (Hepner, Wampold, \& Kivlinghan, 2008) menyimpulkan bahwa bertindak etis tidak hanya terkait dengan mencegah partisipan atau klien dari bahaya, tetapi juga memberikan berkontribusi untuk kesehatan dan kesejahteraan orang lain. Berbuat baik untuk orang lain adalah sebuah aspek kebermanfaatan. Prinsip etika utama ini adalah esensi dari tujuan konseling untuk membantu orang mengatasi masalah yang mereka tidak mampu menyelesaikan sendiri. Prinsip-prinsip etika yang dianjurkan oleh APA dan ACA, dimana telah disebutkan bahwa kode etik memiliki tujuan bagi kesejahteraan dan perlindungan individu dan kelompok dan anggota profesi harus berdedikasi untuk peningkatan perkembangan manusia selama rentang kehidupan.

Selanjutnya, menurut Kitchener (Hepner, Wampold, \& Kivlinghan, 2008) prinsip otonomi diartikan sebagai suatu kegiatan tersebut mestilah berpusat kebebasan partisipan atau klien untuk memilih sendiri apakah mereka bersedia atau tidak, termasuk kebebasan bertindak dan kebebasan memilih. Kemandirian adalah landasan bagi hak subyek untuk secara sukarela berpartisipasi dalam penelitian psikologis, atau sebaliknya untuk tidak berpartisipasi. Menurut Benn (Hepner, Wampold, \& Kivlinghan, 2008) prinsip keadilan menyiratkan kejujuran, kelayakan dan kewajaran. Pada dasarnya, prinsip keadilan didasarkan pada asumsi bahwa setiap orang adalah sederajat. Karakterisitk jenis kelamin dan ras tidak relevan untuk memutuskan akses ke layanan kesehatan mental, tapi ini tidak berarti bahwa jenis kelamin dan ras tidak dipertimbangan bagi perlakuan yang berbeda namun relevan. Konsep keadilan juga menyiratkan hanya memberikan penghargaan atas kerja seseorang, dan kepemilikan hasil kerja seseorang.

Menurut Ramsey (Hepner, Wampold, \& Kivlinghan, 2008) prinsip kebenaran menyiratkan kesetiaan, menepati janji atau kesepakatan, dan loyalitas. Prinsip ini berlaku langsung ke hubungan interpersonal sukarela, termasuk konselor-klien, siswa-guru, dan peneliti-peserta. Isu ketaatan dan kepercayaan adalah pusat untuk profesi membantu seperti konseling. Prinsip kesetiaan penting bagi reputasi profesi serta untuk profesional individu dalam pekerjaan mereka sebagai konselor, pengawas, konsultan, pendidik, dan peneliti.

Dengan demikian hubungan antara ilmu bimbingan dan konseling dengan nilai-nilai kemanusiaan menimbulkan banyak konsekuensi terhadap kehidupan manusia, baik secara langsung maupun tidak langsung. Tentu saja bersinggungan dengan kesejahteraan manusia sebagai tujuan utama kehidupan manusia yang tidak dapat terlepas dari nilai-nilai yang berlaku dan berkembang di tengah-tengah manusia sebagai masyarakat yang berbudaya. Penerapan dan pengembangan keilmuan bimbingan dan konseling harus mempertimbangkan aspek-aspek nilai yang dianut oleh manusia, yang dirumuskan dalam kode etik suatu profesi atau keilmuawan.

\section{SIMPULAN}

Hubungan antara ilmu bimbingan dan konseling dengan nilai-nilai kemanusiaan menimbulkan banyak konsekuensi terhadap kehidupan manusia, baik secara langsung maupun tidak langsung. Tentu saja bersinggungan dengan kesejahteraan manusia sebagai tujuan utama kehidupan manusia. Pada prinsipnya ilmu tidak dapat dilepaskan dari nilai-nilai yang diyakini oleh manusia, terutama dalam mencapai tujuan kesejahteraan. Khususnya kebahagaiaan dan keefektifan hidup manusia.

Sebagai salah satu keilmuan, bimbingan dan konseling fokus pada upaya-upaya memfasilitasi pertumbuhan dan perkembangan manusia. Berbagai upaya pengembangan dan pengaplikasian dilakukan untuk membangun keilmuan yang semakin mapan. Bimbingan dan konseling tidak boleh terlalu bergantung pada ilmu psikologi, karena pembahasan tentang individu sebagai manusia sesungguhnya diserap dari ilmuilmu lain yang juga menjadikan manusia sebagai objek dan subjek bahasannya. Dalam pelaksaan upaya tersebut, bimbingan dan konseling tidak boleh melepaskan diri dari penerapan nilai-nilai dalam setiap upayanya, yang terangkum dalam etika dan estika lisan dan tulisan. Pemisahan antara pengembangan dan 
pengaplikasian ilmu dengan penerapan nilai akan menjerumuskan suatu ilmu pada ketidakbermanfaatan dan pelanggaran terhadap nilai-nilai yang telah dianut oleh manusia sebagai warga masyarakat yang berbudaya.

\section{DAFTAR RUJUKAN}

Cottone, R.R. 1992. Theories and Paradigms of Counseling and Psychotherapy. Massachusetts: Allyn \& Bacoon, Inc.

Gibson, R.L. \& Mitchel, M.H. 2008. Introduction to Counseling and Guidance. New Jersey: Pearson Prentice Hall.

Gladding, S, T. 2012. Counseling: a Comprehensive Profession. New Jersey: Pearson Education.

Hansen, J.C., Stevic, R.R., \& Warner, R.W. 1982. Counseling: Theory and Practice. Massachusetts: Allyn \& Bacoon, Inc.

Hanurawan, Fattah. 2012. Filsafat Ilmu Psikologi. Malang: Universitas Negeri Malang.

Hepner, P.P., Wampold, B.E., \& Kivlinghan, D.M. 2008. Research Desain in Counseling. California: Thomson Brooks/Cole.

Jalaluddin \& Idi, A. 2014. Filsafat Pendidkan: Manusia, Filsafat dan Pendidikan. Jakarta: PT. Rajagrafindo Persada.

Leilich, J. 2004. Is Nature Ever Evil?: Religion, Science and Value. (W. B. Drees, Ed.). New York: Routledge.

Mulyana, Rohmat. 2004. Mengartikulasikan Pendidikan Nilai. Bandung: Alfabeta.

Mumidayeli. 2013. Filsafat Pendidikan. Bandung: PT. Refika Aditama.

Munro, E.A., Manthei, R.J., \&Small, J.J. 1985. Penyuluhan (Counselling) Suatu Pendekatan Berdasarkan Keterampilan. Terjemahan. Jakarta: Ghalia Indonesia.

Nelson-Jones, Richard. 2009. Introduction to Counseling Skill. London. SAGE Publication Ltd.

Pranarka, A.M.W. 1987. Epistimologis Dasar: Suatu Pengantar. Jakarta: Center for Strategic and International Studies.

Sadulloh, U. 2008. Pengantar Filsafat Pendidikan. Bandung. Alfabeta.

Syam, M.N. 2004. Filsafat Kependidikan dan Filsafat Kependidikan Pancasila. Surabaya: Usaha Nasional. 